\title{
Stockholding in Spain
}

\author{
Miguel Ampudia Fraile
}

Received: 8 July 2011 / Accepted: 5 June 2013 / Published online: 2 July 2013

(C) The Author(s) 2013. This article is published with open access at SpringerLink.com

\begin{abstract}
This paper explores the stock holdings of Spanish households. As found for other developed countries, the major part of Spanish households does not participate in the stock market. We analyse the impact that entry costs can have in this decision by looking at how wealth, education and a series of other characteristics affect the probability of households owning stock. We also look at a sample of highly 'sophisticated' households from which we should expect full participation in the stock market. Lastly, we analyse how the decision to hold stocks is related to the decision of holding safe assets, housing, businesses, pension plans and consumer debt.
\end{abstract}

Keywords Portfolio choice $\cdot$ Stockholding $\cdot$ Household finances

JEL Classification $\quad \mathrm{D} 140 \cdot \mathrm{G} 110$

\section{Introduction}

Standard portfolio theory, embodied in the mean-variance expected utility model, predicts that households will always hold part of their portfolio in risky assets, the exact quantity being a function of the equity premium and the volatility of the risky assets' portfolio (see Markowitz 1952; Tobin 1958). Despite this fact, many empirical studies ${ }^{1}$ have shown that the majority of the population does not participate in the stock market, resulting in the well documented stockholding puzzle. The goal of this paper is twofold. First, to offer a comprehensive view of stockholding in Spain. Second, to answer the question: why households do not hold stocks? We base our analysis

\footnotetext{
${ }^{1}$ See Guiso et al. (2002) for a collection of studies conducted in different countries.
}

M. Ampudia Fraile ( $\square)$

141-145 Grosser Hasenpfad Unit 550, 60598 Frankfurt Am Main, Germany

e-mail: mampudia@bu.edu 
on the mean-variance expected utility model with entry costs. We look at how these entry costs, whether monetary or informational, can explain the lack of participation in the stock market. This study contributes to the existing literature by exploring the stockholding pattern in a country not studied before (Spain), while situating it in an international context and explicitly comparing it with the US, by analysing the effect of entry costs through the use of new proxies, and by testing the extent of these hypotheses by looking at a sample of so-called "sophisticated households".

The decision of whether to participate in the stock market or not has a significant impact on the net worth of a household over the long run. Holding stocks is risky due to price fluctuations and non-guaranteed capital; however, refraining from participation in the stock market entails a risk too. With a $6 \%$ average annual equity premium over the past century (see Kocherlakota 1996), a household investing \$100 monthly in the stockmarket for 30 years will retire with $\$ 100,452$ more in savings than a household who had invested the same amounts in long term risk-free assets (such as government bonds). ${ }^{2}$ While most households are fully aware of the former kind of risk, few of them seem concerned about the latter one, which can be thought of as an opportunity cost.

From a macroeconomic point of view, household participation in the stockmarket is also important. A high household participation rate contributes to the liquidity of capital markets, and liquid capital markets allow firms to have a reliable alternate funding channel to traditional banking. This in turn results in faster economic growth. Moreover, by participating in the stockmarket and allocating their funds among industries and sectors, agents are contributing to shape the country's economic structure.

The stockholding puzzle has been widely documented using data from different countries [e.g., Bertaut and Starr-McCluer (2000) analyses the US, Alessie et al. (2000) the Netherlands and Guiso and Jappelli (2000) uses data from Italy] and alternative explanations to it have been proposed such as the combination of high cost of borrowing and uncertain labor earnings (Davis et al. 2006) or the heterogeneity in expectations (Vissing-Jorgensen 2003). ${ }^{3}$ The role of entry costs has been documented for the US by Vissing-Jorgensen (2000) using data from the Panel Study of Income Dynamics. Haliassos and Bertaut (1995) and Bertaut (1998) also identify the role of information costs in deterring stock market participation.

Our paper offers a descriptive view of the state of stockownership in Spain and a more formal analysis of the determinants of stockholding. For this we use a Heckman selection model, which allows us to look at both the decision of holding stock and the amount of stock on the portfolios of those who are holding any. We use a number of household characteristics as regressors following Guiso et al. (2003) for comparability reasons, and adding some economically meaningful variables obtained from our data set. We carry out a direct comparison with the US, which can be considered as the reference case in terms of financial markets development. We also explore the stockholding patterns of a subsample of households which are college-educated, work in the financial industry and whose net worth is above the median of the economy. From

\footnotetext{
2 This number is calculated as the difference in future value between two investments whose annualized returns differ by a $6 \%$ yield. It ignores the uncertainty embedded in the stock price which could cause a major drop in capital if the household retires at a particular bad time for the stock market.

3 See King and Leape (1998) and Haliassos and Bertaut (1995) for good reviews.
} 
here on we will refer to these households as "sophisticated households". Lastly, we use a multivariate probit model to explore how the decision of holding stock is related to the decision of holding other types of assets.

The rest of this paper is organized as follows. Section 2 introduces the model of portfolio selection with entry costs. Section 3 explains the contents and methodology of the data (Encuesta Financiera de las Familias). Section 4 presents the results of the descriptive and econometric analysis. Section 5concludes.

\section{The model: portfolio selection with entry costs}

In the basic expected-utility model, a household who lives for one period has to decide how to allocate its wealth among a variety of risky assets and a risk-free asset that will be liquidated at the end of the period to finance consumption. There are $\mathrm{N}$ states of the world indexed by $i, i=1, \ldots, \mathrm{N}$. The uncertainty is described by the probability $p_{i}$ that state $i$ occurs, with $\sum_{i} p_{i}=1$. Financial markets are assumed to be complete, meaning that for each state $i$, there exists an associated state price (per unit of probability) $\pi_{i} \geq 0$. In other words, the agent must pay $p_{i} \pi_{i}$ at the beginning of the period to increase his consumption by one unit in state $i$. The objective of the household is to maximize its expected utility subject to a budget constraint. This is the classical static portfolio problem of a risk-averse investor in an Arrow-Debrew economy. Formally:

$$
\begin{array}{r}
\max _{C_{1}, \ldots, C_{N}} \sum_{i=1}^{N} p_{i} u\left(C_{i}\right) \\
\text { s.t. } \sum_{i=1}^{N} p_{i} \pi_{i} C_{i}=X
\end{array}
$$

Since Tobin (1958), we know that, under the assumptions of the mean-variance model and in the absence of entry costs, investors will choose a combination of the safe asset and the portfolio of risky assets with the largest Sharpe ratio (the ratio of the average excess return to the standard deviation). Denote by $R$ the gross return of the risk-free asset and by $\widetilde{R}_{S}$ the excess return of the portfolio of risky assets. Under CARA preferences and with $\widetilde{R}_{S}$ distributed normally, the optimal share invested in risky assets $(w)$ is determined as follows:

$$
w=R \frac{E \widetilde{R}_{s}}{\sigma_{s}^{2}} \frac{1}{\rho},
$$

where $\sigma_{s}^{2}$ is the variance of $\widetilde{R}_{S}$, and $\rho$ is the coefficient of relative risk aversion evaluated at wealth level $X R$. This result indicates that for positive expected returns and a finite coefficient of risk aversion every household should invest part of its wealth in risky assets. Thus, we should expect universal participation in the stock market.

In the real world, there exist entry costs to the stock market, both informational and monetary, which may prevent some households from holding stock. Investing in stocks 
requires to set up a brokerage account, monitor it and pay recurring maintenance fees as well as punctual operative ones. In the presence of entry costs, households compare the utility they derive from a riskless portfolio with the utility obtained from their optimal portfolio including risky assets minus the participation costs. Denoting the entry costs by EC, a household will only participate in the stock market if:

$$
E u\left(X(1-w) R+w\left(X \widetilde{R}_{s}-E C\right)\right) \geq u(X R)
$$

The higher the investor's wealth and the larger the potential gains from the equity premium, the more likely is the investor to hold risky securities. Less wealthy households will not enter the stock market since the utility loss suffered from not participating will be lower than the utility loss caused by the fixed cost they need to pay to enter. In other words, it is rational for them to stay out of the market. The model predicts a strong correlation between stock market participation and the investor's wealth, which can in turn explain why not all households invest in stocks. To the extent that they are correlated with entry costs, other individual characteristics may also matter. For instance, educational attainment is an important factor to overcome information costs.

\section{The data: Encuesta Financiera de las Familias}

The Encuesta Financiera de las Familias (EFF) is a survey conducted every three years by the Bank of Spain which collects data on wealth, income, debt, consumption and demographic characteristics from a representative sample of Spanish households. The first survey was conducted in 2002, followed by a second wave in $2005 .^{4}$ The latter one contains a refreshment sample and a panel, with around half of the households interviewed in 2002 being interviewed again in 2005. For our study we will make use of the 2005 wave since it is the most current one.

The 2005 sample contains information on 5,962 households who were interviewed in person between October 2004 and May 2005. Of the total number of households, 2,580 were also interviewed in 2002 and therefore constitute a panel. The survey is divided in the following sections: demographics, real assets and their associated debts, other debts, financial assets, pension plans and life insurance, labor market situation and labor income for each household member, non-labor income in the previous calendar year, means of payments and consumption.

A desirable characteristic of the EFF is the oversampling of wealthy households. Many types of financial assets are only held by the wealthiest households and therefore it is necessary to pay special attention to this group not only for representativeness of the population but also of the aggregate wealth. The missing values have been multiply imputed using relevant econometric techniques. All standard errors calculated in this paper are adjusted for the multiple imputation. For a detailed explanation of the survey methodology Bover (2008).

\footnotetext{
$\overline{4}$ A new wave was conducted in 2008 but the data was not available at the time the paper was written.
} 


\section{Results}

The studies done for other European countries and the US indicate that the level of participation of the general population in the stock market is low, ranging from 7 to $27 \%$ for direct participation and from 15 to $54 \%$ for indirect participation in 1998 (Guiso et al. 2003). We should expect to find a similar pattern for Spain. Moreover, a few characteristics of the Spanish case indicate that we can expect an even lower participation rate. In the first place, Spanish households show a relatively high preference for owning their main residence (81.3\% of Spanish households own their primary residence, while only $68.3 \%$ of US households do so). Investment in housing usually compromises all the available savings of the household, especially in the case of younger ones, which precludes them from investing in other type of assets. Secondly, the level of financial literacy of Spanish households is low relative to that of other developed countries. Jappelli (2010) compares the level of economic literacy (used as a proxy for financial literacy) using data from the IMD World Competitiveness Yearbook from 1995 to 2004, and ranks Spain far behind the US and the rest of western European countries (except Italy).

For our econometric analysis in Sect. 4.2, we will analyse the Spanish case and we will compare it explicitly and in detail with the US one. For this comparison, we will make use of the Survey of Consumer Finances (SCF). The reason for doing the comparison with the US is twofold. First, the US can be considered as a benchmark case of financial development and participation in financial markets. Second, both the EFF and the SCF provide us with some extra benefits that we cannot find in any other surveys. In the first place, due to the close structure of both surveys, we can do a comparison using exactly the same variables in our analysis. In addition, and more importantly, both the EFF and the SCF provide an oversampling of rich households which allows to capture the whole distribution of wealth in the population. For a detailed explanation on the SCF data see Bucks et al. (2009).

\subsection{Descriptive analysis}

In order to assess the holding of risky assets by households two different measures are employed. The first one, referred to as direct stock, consists of traded and non-traded stocks held directly by the households. The second one, indirect stock holding, is a broader measure which includes mutual funds which invest mainly in stock. ${ }^{5}$ Note that we do not include participation through pension plans since we do not have data on their specific asset composition.

The level of households' participation in the stock market in Spain is low. In 2005, $13.05 \%$ of Spanish households held stock directly and $16.68 \%$ of them did so indi-

\footnotetext{
5 Although we have information on households owning other financial products which could be consider riskier and more sophisticated than stocks (i.e. options, futures and swaps) we do not include them here since we do not have information about their market value (this is a deliberate point made in the survey construction since it is sometimes not possible to know the value of such products and even if known it is not very relevant due to the non-linearity of their pay-offs). Anyway, there are only four households who declare holding these type of products and not holding stock.
} 
Table 1 Households owning stocks by demographic characteristics

\begin{tabular}{lclll}
\hline & Direct stock & S.E. & Indirect stock & S.E. \\
\hline All sample & 13.1 & $(0.67)$ & 16.7 & $(0.75)$ \\
College degree & 31.6 & $(2.4)$ & 37.8 & $(2.4)$ \\
No college degree & 9.2 & $(0.6)$ & 12.3 & $(0.7)$ \\
Age 16-30 & 8.5 & $(2.4)$ & 10.4 & $(2.7)$ \\
Age 31-40 & 10.2 & $(1.4)$ & 14.0 & $(1.7)$ \\
Age 41-50 & 14.4 & $(1.5)$ & 19.6 & $(1.7)$ \\
Age 51-60 & 20.0 & $(1.9)$ & 22.7 & $(2.0)$ \\
Age 61-70 & 13.8 & $(1.6)$ & 17.2 & $(1.7)$ \\
Age 70+ & 9.0 & $(1.2)$ & 12.7 & $(1.4)$ \\
I wealth quartile & 2.3 & $(0.6)$ & 3.8 & $(0.9)$ \\
II wealth quartile & 6.2 & $(1.1)$ & 8.9 & $(1.2)$ \\
III wealth quartile & 11.6 & $(1.3)$ & 15.7 & $(1.4)$ \\
IV wealth quartile & 32.1 & $(1.8)$ & 38.4 & $(1.9)$ \\
I income quartile & 4.7 & $(0.9)$ & 6.9 & $(1.0)$ \\
II income quartile & 5.8 & $(0.9)$ & 7.7 & $(1.0)$ \\
III income quartile & 11.9 & $(1.5)$ & 15.4 & $(1.7)$ \\
IV income quartile & 29.8 & $(1.9)$ & 36.7 & $(2.1)$ \\
\hline
\end{tabular}

All values are percentages

rectly. These figures are clearly far from universal participation and relatively low compared with other European countries (for data of 1998, only Italy showed a lower participation rate). Table 1 shows that $31.62 \%$ of households with a college degree held stock directly; whereas among those households who do not hold a college degree, the statistic drops to $9.19 \%$. For the indirect holding of stocks the values are 37.80 and $12.30 \%$ respectively. When looking at the age of the households holding stock, the data shows a hump-shaped pattern; with ownership increasing with age, peaking at the age group 51-60 and decreasing afterwards. The distribution along levels of income is flat for the first income deciles, starts growing slowly when the median of the distribution is reached and grows substantially faster for the last two deciles of the distribution. This pattern is exhibited in both the direct and indirect stock holding measures (see Fig. 1). Wealth and stockholding are positively and monotonically related, with large increases in between deciles for the richest households; $22.29 \%$ of households own stock directly and $27.81 \%$ do so indirectly in the next to last decile. The numbers for the last decile are 49.19 and $57.25 \%$ respectively.

\subsection{Econometric analysis}

The existence of entry costs, whether these are informational or monetary, will result in richer and more educated households exhibiting a higher participation rate in the stock market. In order to test this hypothesis, and following the many studies done 
(a) By income deciles

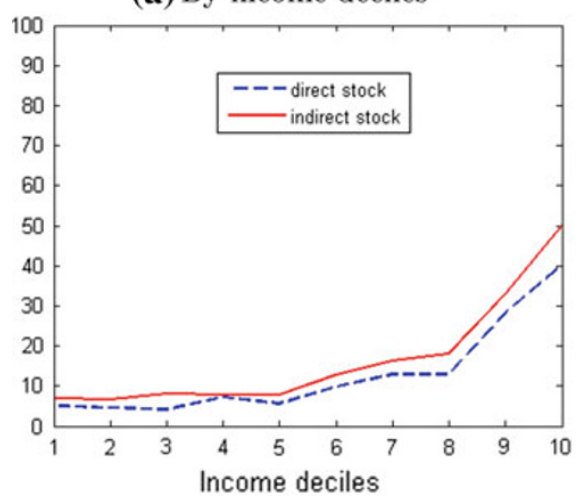

(b) By wealth deciles

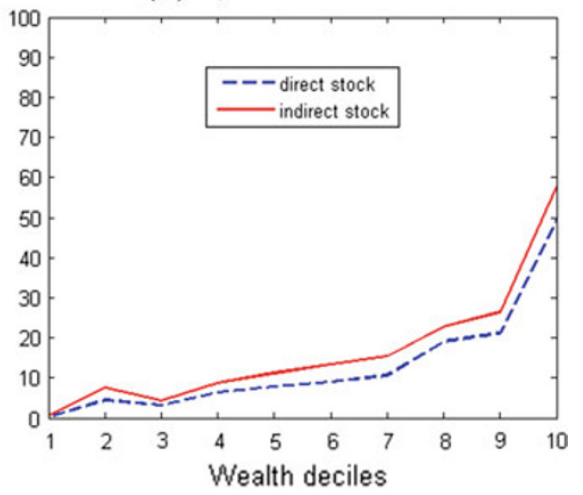

Fig. 1 Percentage of households owning stocks directly or indirectly

for diverse countries, ${ }^{6}$ and in particular the work of Guiso et al. (2003), we regress stockownership on a series of variables including income, wealth and education. The econometric analysis can be carried out following different methods. There are two regressions to run, one for stockownership and one for the share that the stock owned represents in the overall portfolio. Moreover, it makes sense to think that there is a correlation between the decision of whether to hold risky financial assets or not and the decision on the amount of these assets held. For this reason, the most favoured treatment in the literature is to make use of a sample selection model. ${ }^{7}$ We follow this approach by modelling the demand for stocks as a two-stage decision process, first households make a participation decision and then they decide on the amount of assets they want to hold.

For comparability purposes, following Guiso et al. (2003), the following independent variables are included in the regression: age, income, wealth, education, marital status and family size. Income, wealth and education are variables which exhibit a high positive correlation; it is important, therefore, to disentangle the effect that each one of them can have on the decision to hold stocks. Traditional portfolio theory tells us that wealth should not affect the decision of whether to hold stocks or not, since these (or an equivalent risky asset) should be part of every household's properly-diversified portfolio. However, if there are entry costs, we should expect wealth to play a key role in the stock ownership decision.

In order to use the Heckman selection model, it is necessary to specify suitable identification restrictions; that is, variables which affect the decision of whether to hold risky financial assets or not, but that they do not affect the decision of the amount of the assets that will be held. The variables we employ are: the use of on-line banking and the fact that the household head works in the financial industry. We argue that these two variables have an important effect on the fixed cost of participating in the stock market but a negligible one on the variable cost of investment. Once an investor has set

\footnotetext{
6 Studies for the US, the UK, Italy, Germany and the Netherlands are collected in Guiso et al. (2002).

7 See Bertaut and Starr-McCluer (2000).
} 
up a brokerage account and he has learned the operative details, sending orders to the market has a very low cost (a phone call maximum), and therefore it cannot be reduced much more. However, the fixed cost of entering is higher, and it seems reasonable to think that it can be lowered if the potential investor works in the financial industry (thus lowering the informational cost) or uses the internet to handle his financial operations (which lowers both the informational and the financial cost). To justify our choice of selection variables we also report the results of running a simple OLS regression instead of the Heckman selection model. The coefficients reported in both models differ substantially, thus indicating that our selection variables are meaningful (see the Appendix for the full results of the OLS regression for both the Spanish and US data). ${ }^{8}$

Results for the selection model for both Spain and the US are contained in Tables 2 and 3. For comparability purposes and ease of interpretation, the coefficients we report for the first-stage regression of the selection model represent the effect of the different explanatory variables on the probability of owning stock. Age is not significant in the lower bins (up to age 50 in Spain and up to age 40 in the US), but it is significant at the $1 \%$ level for the bins containing ages over the aforementioned ones. This pattern of behaviour might seem at odds with what traditional financial planning advocates for, but the result is consistent with the findings of Guiso et al. (2003) for the US, the UK, Germany, France and the Netherlands. Age plays a more important role in the case of the US, especially for the upper bins. Both income and wealth are highly significant (at the $1 \%$ level) and have a significant effect on the decision of holding stock, being the effect bigger in both cases for Spain. Education is also significant at the $1 \%$ level. The effect of this variable is almost double for the US case compared with Spain.

Now we look at the variables that we believe could have an impact on the decision of holding stock if entry costs were present. These are, for Spain, the use of on-line banking and whether the household head works in the financial industry or not; and for the US, how much does the household shops around when looking for investment opportunities. We also want to control for the attitude towards risk of the households when investing their assets. It could be that the results obtained are just derived from the fact that richer and more educated households are less risk averse and this is why they are willing to participate more in the stock market.

First of all, controlling for the risk attitude of the households explains an important part of the puzzle by itself. The variable reflecting the household's attitude towards risk when making an investment is significant for both countries for the case when the household is willing to take on some risk, the case when the household is willing to take on substantial risk and the case when the household is willing to take on a lot of financial risk (the results for this last variable are not very reliable due to the small number of observations available). For Spain, the effects on the probability of holding stock decrease with the amount of risk the household is willing to take, while in the US we observe the opposite pattern; the more risk the household is willing to assume, the

\footnotetext{
8 Note that for the US case we use as our selection variable 'degree of research done before buying an investing product', following Bertaut and Starr-McCluer (2000). Due to privacy concerns the FRB does not release publicly the information we would need to construct the selection variables we use in the Spanish case.
} 
Table 2 Heckman selection model: Direct stock holding

\begin{tabular}{|c|c|c|c|c|}
\hline & \multicolumn{2}{|l|}{ Spain } & \multicolumn{2}{|l|}{ US } \\
\hline & Ownership & Share & Ownership & Share \\
\hline \multirow[t]{2}{*}{ Married } & $0.051 * * *$ & -0.032 & $0.105 * * *$ & 0.018 \\
\hline & $(0.012)$ & $(0.023)$ & $(0.007)$ & $(0.017)$ \\
\hline \multirow[t]{2}{*}{ Family size } & 0.0004 & -0.013 & $-0.008 * * *$ & 0.006 \\
\hline & $(0.005)$ & (0.009) & $(0.003)$ & $(0.003)$ \\
\hline \multirow[t]{2}{*}{ College } & $0.109 * * *$ & -0.011 & $0.189 * * *$ & 0.037 \\
\hline & $(0.011)$ & $(0.022)$ & $(0.005)$ & $(0.027)$ \\
\hline \multirow[t]{2}{*}{ Age $31-40$} & 0.007 & -0.013 & 0.004 & $-0.075^{* * *}$ \\
\hline & $(0.032)$ & $(0.073)$ & $(0.013)$ & $(0.020)$ \\
\hline \multirow[t]{2}{*}{ Age 41-50 } & 0.042 & -0.051 & $0.077 * * *$ & $-0.047 * *$ \\
\hline & $(0.030)$ & $(0.072)$ & $(0.012)$ & $(0.022)$ \\
\hline \multirow[t]{2}{*}{ Age $51-60$} & $0.110 * * *$ & -0.049 & $0.114 * * *$ & 0.031 \\
\hline & $(0.030)$ & $(0.073)$ & $(0.011)$ & $(0.025)$ \\
\hline \multirow[t]{2}{*}{ Age $61-70$} & $0.139 * * *$ & -0.024 & $0.166^{* * *}$ & $0.062 * *$ \\
\hline & $(0.030)$ & $(0.072)$ & $(0.012)$ & $(0.030)$ \\
\hline \multirow[t]{2}{*}{ Age 70+ } & $0.173 * * *$ & 0.047 & $0.251 * * *$ & $0.199 * * *$ \\
\hline & $(0.030)$ & $(0.074)$ & $(0.012)$ & $(0.038)$ \\
\hline \multirow[t]{2}{*}{ Income } & $6.31 \mathrm{e}-07 * * *$ & $-5.60 \mathrm{e}-10$ & $5.27 \mathrm{e}-09 * * *$ & $1.86 \mathrm{e}-09^{* * *}$ \\
\hline & $(1.04 \mathrm{e}-07)$ & $(3.20 \mathrm{e}-08)$ & $(7.02 \mathrm{e}-10)$ & $(6.38 \mathrm{e}-10)$ \\
\hline \multirow[t]{2}{*}{ Net wealth } & $5.24 \mathrm{e}-08 * * *$ & $4.10 \mathrm{e}-09 * * *$ & $3.61 \mathrm{e}-10 * * *$ & $4.80 \mathrm{e}-10^{* * * *}$ \\
\hline & $(4.20 \mathrm{e}-09)$ & $(5.18 \mathrm{e}-09)$ & $(4.19 \mathrm{e}-11)$ & $(5.27 \mathrm{e}-11)$ \\
\hline \multirow[t]{2}{*}{ Seeking some risk } & $0.202 * * *$ & -0.035 & $0.188 * * *$ & $0.085 * * *$ \\
\hline & $(0.011)$ & $(0.026)$ & $(0.007)$ & $(0.029)$ \\
\hline \multirow[t]{2}{*}{ Seeking fair risk } & $0.181 * * *$ & $0.059^{*}$ & $0.249 * * *$ & $0.123 * * *$ \\
\hline & $(0.026)$ & $(0.038)$ & $(0.008)$ & $(0.037)$ \\
\hline \multirow[t]{2}{*}{ Seeking a lot of risk } & $0.160 * * *$ & 0.067 & $0.269 * * *$ & $0.158 * * *$ \\
\hline & $(0.041)$ & $(0.059)$ & $(0.013)$ & $(0.040)$ \\
\hline \multirow[t]{2}{*}{ Work in finance } & $0.080 * * *$ & & & \\
\hline & $(0.022)$ & & & \\
\hline \multirow[t]{2}{*}{ Use on-line banking } & $0.059 * * *$ & & & \\
\hline & $(0.013)$ & & & \\
\hline \multirow[t]{2}{*}{ Degree of shopping } & & & $0.012 * * *$ & \\
\hline & & & $(0.002)$ & \\
\hline \multirow[t]{2}{*}{ Constant } & $-2.086^{* * *}$ & $0.569 * * *$ & $-2.200 * * *$ & -0.035 \\
\hline & $(0.134)$ & $(0.100)$ & $(0.050)$ & $(0.125)$ \\
\hline \multirow[t]{2}{*}{ Mills ratio } & $-0.115^{* * *}$ & & $0.138 * * *$ & \\
\hline & 0.032 & & 0.054 & \\
\hline Observations & 5,962 & 5,962 & 4,418 & 4,418 \\
\hline
\end{tabular}

Standard errors in parentheses

$* * * p<0.01, * * p<0.05, * p<0.1$ 
Table 3 Heckman selection model: Indirect stock holding

\begin{tabular}{|c|c|c|c|c|}
\hline & \multicolumn{2}{|l|}{ Spain } & \multicolumn{2}{|l|}{ US } \\
\hline & Ownership & Share & Ownership & Share \\
\hline \multirow[t]{2}{*}{ Married } & $0.044 * * *$ & -0.027 & $0.139 * * *$ & $-0.034 * * *$ \\
\hline & $(0.012)$ & $(0.020)$ & $(0.006)$ & $(0.010)$ \\
\hline \multirow[t]{2}{*}{ Family size } & -0.005 & $-0.016^{* *}$ & $-0.018 * * *$ & -0.004 \\
\hline & $(0.005)$ & $(0.008)$ & $(0.002)$ & $(0.003)$ \\
\hline \multirow[t]{2}{*}{ College } & $0.108 * * *$ & 0.002 & $0.182 * * *$ & 0.013 \\
\hline & $(0.012)$ & $(0.020)$ & $(0.005)$ & $(0.011)$ \\
\hline \multirow[t]{2}{*}{ Age $31-40$} & $0.050 *$ & 0.01 & $0.090 * * *$ & $0.044 * * *$ \\
\hline & $(0.034)$ & $(0.069)$ & $(0.010)$ & $(0.015)$ \\
\hline \multirow[t]{2}{*}{ Age 41-50 } & $0.089 * * *$ & 0.017 & $0.182 * * *$ & $0.067 * * *$ \\
\hline & $(0.032)$ & $(0.068)$ & $(0.010)$ & $(0.017)$ \\
\hline \multirow[t]{2}{*}{ Age $51-60$} & $0.131 * * *$ & 0.011 & $0.201 * * *$ & $0.073 * * *$ \\
\hline & $(0.033)$ & $(0.069)$ & $(0.010)$ & $(0.017)$ \\
\hline \multirow[t]{2}{*}{ Age $61-70$} & $0.187 * * *$ & 0.045 & $0.213 * * *$ & $0.081 * * *$ \\
\hline & $(0.033)$ & $(0.069)$ & $(0.011)$ & $(0.018)$ \\
\hline \multirow[t]{2}{*}{ Age 70+ } & $0.220 * * *$ & $0.131 * *$ & $0.237 * * *$ & $0.138 * * *$ \\
\hline & $(0.032)$ & $(0.071)$ & $(0.011)$ & $(0.019)$ \\
\hline \multirow[t]{2}{*}{ Income } & $1.24 \mathrm{e}-06^{* * *}$ & $6.30 \mathrm{e}-08 * *$ & $4.00 \mathrm{e}-08 * * *$ & $1.51 \mathrm{e}-09 * * *$ \\
\hline & $(1.42 \mathrm{e}-07)$ & $(3.10 \mathrm{e}-08)$ & $(4.48 \mathrm{e}-09)$ & $(4.45 \mathrm{e}-10)$ \\
\hline \multirow[t]{2}{*}{ Net wealth } & $6.68 \mathrm{e}-08 * * *$ & $4.50 \mathrm{e}-09 * * *$ & $1.86 \mathrm{e}-09 * * *$ & $2.91 \mathrm{e}-10^{* * * *}$ \\
\hline & $(5.47 \mathrm{e}-09)$ & $(1.20 \mathrm{e}-09)$ & $(2.31 \mathrm{e}-10)$ & $(4.41 \mathrm{e}-11)$ \\
\hline \multirow[t]{2}{*}{ Seeking some risk } & $0.218 * * *$ & 0.004 & $0.237 * * *$ & $0.029 *$ \\
\hline & $(0.012)$ & $(0.022)$ & $(0.006)$ & $(0.016)$ \\
\hline \multirow[t]{2}{*}{ Seeking fair risk } & $0.181 * * *$ & $0.093 * * *$ & $0.301 * * *$ & $0.100 * * *$ \\
\hline & $(0.030)$ & $(0.036)$ & $(0.007)$ & $(0.018)$ \\
\hline \multirow[t]{2}{*}{ Seeking a lot of risk } & $0.135 * * *$ & $0.189 * * *$ & $0.223 * * *$ & $0.128 * * *$ \\
\hline & $(0.046)$ & $(0.055)$ & $(0.013)$ & $(0.019)$ \\
\hline \multirow[t]{2}{*}{ Work in finance } & $0.097 * * *$ & & & \\
\hline & $(0.024)$ & & & \\
\hline \multirow[t]{2}{*}{ Use on-line banking } & $0.080 * * *$ & & & \\
\hline & $(0.014)$ & & & \\
\hline \multirow[t]{2}{*}{ Degree of shopping } & & & $0.011 * * *$ & \\
\hline & & & $(0.002)$ & \\
\hline \multirow[t]{2}{*}{ Constant } & $-2.014 * * *$ & $0.559 * * *$ & $-2.200 * * *$ & $0.413 * * *$ \\
\hline & $(0.134)$ & $(0.088)$ & $(0.050)$ & $(0.045)$ \\
\hline \multirow[t]{2}{*}{ Mills ratio } & $-0.092 * * *$ & & $-0.052 * *$ & \\
\hline & 0.029 & & 0.024 & \\
\hline Observations & 5,962 & 5,962 & 4,418 & 4,418 \\
\hline
\end{tabular}

Standard errors in parentheses

$* * * p<0.01, * * p<0.05, * p<0.1$ 
higher the probability he owns stock. In all cases, the effects are substantial in absolute terms, being willing to bear on some risk when investing increases the probability of owning stock by 0.20 percentage points in Spain and by 0.18 percentage points in the US. These effects are also important in their relative size, being much so for Spain, where we find an effect as large as twice the effect of having a college degree. The fact that the risk attitude plays a role in the holding of stocks is an indication of the households' misinformation about the stock market. A frictionless model will have households owning stock no matter what their attitude towards risk is. This one should influence the share of stock held, but not the participation decision. It is also important to note the relative size of this effect and the fact that seeking some or substantial risk have an effect of the same dimension. This is not surprising since we are looking at the decision of just holding stock, a decision which we expect to be positive for any agent willing to take on any financial risk. We would expect that households willing to take on different amounts of risk would differ on the amount of risky assets that they hold, but not on the decision whether to hold them or not.

We also look at the effect of the household being an on-line banking user. The fact that stocks can be bought and sold through on-line brokers brings down participation and information costs. On-line trading is usually less costly than the traditional telephone or physical services in terms of fees, plus it is less time consuming and allows the investor to access a great wealth of information with reduced effort. The effect of being an on-line banking user is significant at the $1 \%$ level.

If information costs are one of the reasons why households do not participate in the stock market, a higher participation rate should be expected from those households working in the financial services industry. This is exactly what we find, with households whose head works in the financial services industry having a probability of owning stock much higher than those working in other industries.

For the US, the effect of shopping around when looking for investment opportunities is also significant at the $1 \%$ level.

Summarizing, the main factors affecting stock holding in both countries are age, income, wealth and education. Age is a more important factor in the US than in Spain, while income and wealth have a bigger effect in Spain. The effect of education is almost double in the US than in Spain and the risk aversion exhibited by the household has opposite effects on both countries (in the US, the more financial risk a household is willing to assume the higher the probability it owns stock, while the opposite is observed for Spain). These differences may reflect the unequal degree of development of financial markets in both countries. The higher degree of competition and development existing in the US results in more complex markets but with lower entry costs. Investors in the US have more options to choose from when making their investment decisions, more information and access to a more diverse supply of service providers (brokers, financial advisors, fund managers...). This complexity results in education and age playing a more important role in the investment decision. On the other hand, the more competition present in the market makes it cheaper to own stock. Because of this, income and wealth play a more important role in the stock holding decision in Spain.

The results for the share of funds allocated to stocks differ greatly between the direct or indirect holding of stocks. In the first case, the only significant variable is the net 
Table 4 Decomposition of stock market participation rates

\begin{tabular}{llll}
\hline & Total difference & Difference due to covariates & Difference due to coefficients \\
\hline Direct stock & 0.0704 & 0.1054 & -0.0350 \\
Indirect stock & 0.2185 & 0.1657 & 0.0528 \\
\hline
\end{tabular}

All values are percentages

wealth of the household, while in the latter case, family size, old age, income, wealth and attitude towards financial risk are all significant at the $5 \%$ level. These results are contradictory to both what classical financial theory and conventional financial advise postulate. According to the basic mean-variance model, rich households should behave as scaled-up version of less wealthy ones if we are controlling for risk aversion. The results in Tables 3 and 4 show that the share of stock is still positively correlated with wealth, although the quantitative effect is very small. With respect to age, the behaviour of households is opposite to the one advocated by conventional financial wisdom; older households hold a higher share of their portfolios in risky financial assets. The results for the US reveal some differences with Spain. Age, income, wealth and risk aversion all play a role, not only in the share of risky assets held for the case of indirect stock, but also for the direct one. The disagreement with classical financial theory and conventional financial advise is only but magnified in the American case.

Following the work of Christelis et al. (2013) we can go one step further in our country comparison and decompose the difference between the stock market participation rate observed in both countries into two components: a part that corresponds to the structural difference between countries and a part which is due to the difference in household characteristics. ${ }^{9}$ In order to perform this exercise we estimate a probit model for each country using the same regressors in both cases. Note that we cannot make use of the Heckman selection model we have already estimated since the selection variables are different for each country. More specifically, the procedure consists on first estimating a probit model for each country and with it constructing the average predicted probability of participating in the stock market ( $p^{U S}$ for the US and $p^{S}$ for Spain). Then, we construct the average predicted probability of participation for each country if they faced the coefficients of the other country $\left(\hat{p}^{U S}\right.$ and $\left.\hat{p}^{S}\right)$. The difference in participation rates can be decomposed into two components:

$$
p^{U S}-p^{S}=\left(p^{U S}-\hat{p}^{U S}\right)+\left(\hat{p}^{U S}-p^{S}\right),
$$

The first term is what Christelis et al. (2013) refer to as "covariate effects", which is the difference in participation rates that arises because of the differences in household characteristics across countries. The second term, the "coefficient effects", capture the difference in participation rates arising from differences between the estimated coefficients.

Table 4 contains the results of the estimation. ${ }^{10}$ The predicted difference in participation for direct stock between the US and Spain is $7.04 \mathrm{pp}$, all of which (and more)

\footnotetext{
${ }^{9}$ I am thankful to an anonymous referee for suggesting this comparison.

10 Full estimation results can be found in Appendix C.
} 
comes from the difference between household characteristics. If US households had the same characteristics as Spanish ones, they would participate in the stock market $3.50 \mathrm{pp}$ less than actual Spanish households do. In the case of indirect stockholding, the predicted difference in participation is of $21.85 \mathrm{pp}$. In this case, most of the difference is also attributed to differences in household characteristics. If US households were to have the same characteristics as Spanish households, their rate of participation will only be 5.28 pp higher than the one of current Spanish households.

\subsection{Sophisticated households}

All the results presented above show that the existence of monetary and informational entry costs play a role in the decision of holding risky assets. In order to see if the existence of these costs alone can explain the stockholding puzzle, or if, by the contrary, further explanations should be explored, we look at the risky assets portfolio of a selected subsample of the Spanish households. Specifically, we are going to select households from which, as indicated by their demographic characteristics, we should expect unanimous participation in the stock market. These will be households in which the reference person or his/her partner hold a college degree and work in the financial industry. Plus, we will only look at households that are above the median wealth. Not surprisingly, these households have a much higher degree of participation in the stock market than the average one: $62.13 \%$ of them hold stock directly and $72.33 \%$ do so if we include the holding of mutual funds invested mainly in stocks. However, this is still well far from universal participation. And we are looking at an extremely restrictive sample (only 128 of the 5,962 households, or $2.14 \%$ of the sample, comply with all these criteria). ${ }^{11}$ If we cannot find universal participation (not even close to it) even among these households, it is clear that there have to be more factors affecting the decision of owning stock. It is hard to imagine which extra frictions could be introduced in the literature's reference model, and it may be necessary to explore alternative theoretical models to explain this puzzle. This is obviously beyond the scope of this paper.

We can also compare these results with a sample of sophisticated households from the US. Unfortunately, we cannot identify which household heads work in the financial industry in the SCF data. Members of the household are asked the industry they work for, but due to privacy concerns, the FRB has collapsed the answer codes to this question, such that we cannot distinguish the financial sector from Repair and Maintenance, Security Services, Employment and Business Support Services, Software Publishing and Data Processing. We argue that the impact of this distortion should not be high (see the Appendix B for a detailed explanation for this affirmation). So we are going to define the US sophisticated households as those in which the household head or his/her partner hold a college degree, work in one of the aforementioned industries and whose wealth is above the median of the population.

\footnotetext{
11 Because the sample size is so small the estimations present large standard errors. Even still, the results are statistically far from universal participation. The $95 \%$ confidence interval for holding direct stock is 44.7-79.6\% and for indirect stock 56.7-88.0\%.
} 
Table 5 Portfolio structure of sophisticated households

\begin{tabular}{lllll}
\hline & Sophisticated households & & All households & \\
\hline Main house & $97.7 \%$ & $(2.1)$ & $81.3 \%$ & $(0.8)$ \\
Other real estate & $58.0 \%$ & $(9.4)$ & $34.5 \%$ & $(0.9)$ \\
CD's & $26.1 \%$ & $(7.6)$ & $16.5 \%$ & $(0.7)$ \\
Stocks & $61.5 \%$ & $(9.0)$ & $13.1 \%$ & $(0.7)$ \\
Mutual funds & $50.8 \%$ & $(9.8)$ & $8.7 \%$ & $(0.6)$ \\
Pension funds & $78.8 \%$ & $(6.8)$ & $28.5 \%$ & $(0.9)$ \\
Life insurance & $58.7 \%$ & $(9.3)$ & $23.3 \%$ & $(0.9)$ \\
Bonds & $7.7 \%$ & $(4.3)$ & $1.5 \%$ & $(0.2)$ \\
Observations & 128 & & 5.962 & \\
\hline
\end{tabular}

Values in table indicate percentage of households owning each type of asset

Values in parenthesis indicate standard errors

Since we are dealing with very small samples, and therefore the high standard errors of our estimates could make more difficult to get useful information from the comparison, we are going to use bootstrapping to get the values for our estimates and their standard errors. Using 100,000 bootstrapped samples, $47.03 \%$ (s.d of $1.07 \%$ ) of the US sophisticated households hold stock directly and $80.77 \%(0.85 \%)$ do so indirectly. ${ }^{12}$ For their Spanish counterparts, the estimates are $62.13 \%(4.28 \%)$ and $72.33 \%$ (3.94\%), respectively. So Spanish sophisticated households hold substantially more direct stock but substantially less indirect one. These results are consistent with what we found for the general population.

Table 5 shows the degree of participation in each asset category of both sophisticated households and all the households in the sample. The main conclusion to be drawn is that sophisticated households hold more diversified portfolios. The proportion of these households that hold each asset category is higher than the proportion of households that hold the asset for the whole population. Although the difference is specially significant for the different financial assets: 50.8 vs $8.7 \%$ for mutual funds, 78.8 vs $28.5 \%$ for pension funds, 58.7 vs $23.3 \%$ for life insurance, 26.1 vs $16.5 \%$ for CD's and savings accounts, ${ }^{13} 7.7$ vs $1.5 \%$ for bonds; sophisticated households are also more prone to own real assets, 97.7 vs $81.3 \%$ for the main home and 58.0 vs $34.5 \%$ for other real estate. It is important to note that the sample of sophisticated households exhibits a much higher average net wealth than the full sample of households, and thus, the results from Table 4 may be driven by wealth. This is not relevant. We have arbitrarily defined a sample of sophisticated households with the idea of capturing households from who we expect an overwhelming participation in the stock market. The specific characteristics that make them participate more are not important here, just the fact that they do participate more.

\footnotetext{
12 The number for the indirect stock holding does not include participation through pension plans in order to make it comparable with the Spanish case. If we were to include this one, the participation rate will be $85.42 \%(0.76 \%)$, not changing any of our conclusions.

13 Specifically, this category includes all kind of savings accounts and deposits which cannot be used for making payments through a debit card or a check.
} 


\subsection{Multivariate probit}

The decision whether to hold stocks or not is part of the overall portfolio composition problem. This implies that households should make this decision at the same time they decide whether to hold other financial assets, real assets or debt. The interest of studying these decisions jointly is clear since the household is constrained by limited funds which it should distribute among the different competing investment opportunities. A clear example of this are younger households who face the purchase of their first main residence. ${ }^{14}$

Using our extensive data it is possible to study all these decisions with one model. In particular, we are going to estimate a multivariate probit model in order to analyse the decision of holding different types of assets. The model we estimate looks at whether the household owns stock, safe financial assets, real assets, businesses, pension plans and consumer debt. The explanatory variables are the same as before. The model is estimated using Geweke, Hajivassiliou and Keane's simulation method to approximate the multivariate normal distribution (Green 1997).

Results are displayed in Table 6. In order to be able to compare the magnitude of the impact of our different variables, the coefficients we report represent the effect on the probability of holding the specific asset. The effect of age on the households' portfolio composition decision is mixed. Mainly, age seems not to be a significant factor in the ownership of most assets. However, age plays a role when looking at businesses ownership for the oldest households, who are substantially less likely to hold them. Also, age is significant at the $5 \%$ level for the decision to hold a pension plan. Not surprisingly, households in their working period of their life span are more likely to hold pension plans that those already retired. The effect is greater as we come close to the retirement age (households in between ages 51 and 60 are 0.21 points more probable to hold a pension plan than the reference group) and shows a negative and highly significant coefficient after this one. Age has also an effect on the decision to hold debt. Households in between the ages of 30 and 50 are more likely to hold some kind of debt, while this probability starts decreasing with age after the 60 year mark. This result can be explained by the desire to conduct some consumption smoothing, and it is fully consistent with the life-cycle model.

Having a college degree increases the probability of holding stock and subscribing to a pension plan. This is an expected result in the presence of information costs that the household has to overcome in order to invest in more sophisticated financial products. The effect of college education is negative on the probability of owning real assets and businesses. This last result is surprising since it would somehow indicate that more educated households are more risk averse or less entrepreneurial. However, the fact that these households present a higher probability of owning stock also indicates that these households have more options where to look for risk. In fact, the size of the effect of both variables is equivalent, around 0.07 points. Lastly, the coefficient for the debt equation is negative and significant at the $1 \%$ level.

\footnotetext{
14 See King and Leape (1998) and Bertaut and Starr-McCluer (2000) for studies examining joint portfolio decisions.
} 


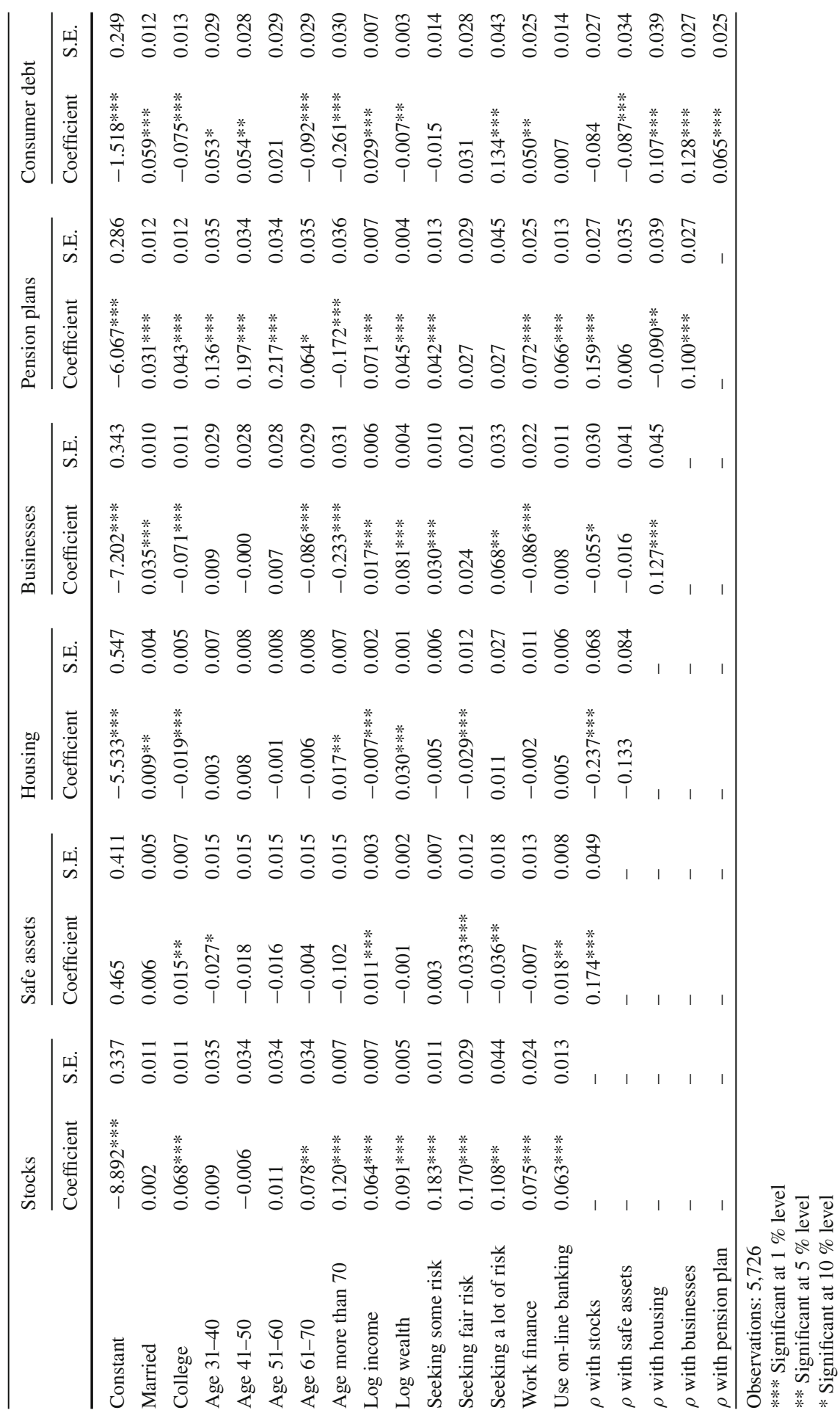


The effect of wealth is significant at the $1 \%$ level and positive for all categories of assets except for safe assets, for which wealth is not significant at the $10 \%$ level. The effect on consumer debt is negative and significant at the $5 \%$ level. When wealth is small, the reward for seeking out different investments is not high enough to compensate for the cost of this search, but as the wealth of the households increases, not looking out for different investments other than safe assets has in fact a high opportunity cost. Income has a significant and positive effect in the case of stocks, safe assets, pension plans and debt.

As might be expected, risk aversion plays a role in the decision to hold stocks, businesses and safe assets. The effect is positive for the first two and negative for the last. The size of the effect is remarkable for the decision to hold stock, households who seek more risk in their investments are 0.17 points more probable to invest in stock. It is interesting to note that risk aversion does not play a role in the decision of whether to hold debt or not.

Working in the financial industry has a positive and significant effect on the decision to hold stocks, pension plans and debt, and a negative and significant effect of the decision to hold housing and businesses. This seems to indicate the existence of some sort of "professional bias". Although it is not in the scope of this paper, it would be interesting to see if these households are holding more efficient portfolios, or by the contrary, this "professional bias" is leading them to a higher exposure to financial assets than desirable. Looking at the results from the previous section, our conjecture is that these households are facing the first situation.

The effect of using on-line banking is positive and significant at the $5 \%$ for the cases of holding stocks, bank accounts and pension plans, being the effect on the first and last variables relatively substantial. This is not surprising if we take the on-line banking variable as a determinant of household financial sophistication, or at least as a tool to reduce the costs of entering any of these markets.

Lastly, we look at the correlation among assets. There is a positive, and significant at the $5 \%$ level, correlation between the decision of holding stocks and the decision of holding safe assets, and a positive and significant correlation between the decision of holding stocks and decision of holding pension plans. On the other hand, the correlation is negative for the decision of holding stock and the decision of holding housing and between the decision of holding stock and the decision of holding debt. The decision of holding safe assets is negatively correlated with that of holding housing and positively correlated with that of holding debt. The decision of holding housing is positively correlated with that of holding debt, as they are the decisions of holding pension plans and debt.

\section{Conclusion}

The participation rate of Spanish households in the stock market is low, both in absolute and relative standards. Spain is among the European countries which exhibit a lower participation rate and it is far behind the US. We have shown that this can be partially explained by the existence of monetary and informational entry costs, wealthier and more educated households have a higher probability of owning stock than their 
counterparts. However, the existence of these costs alone is not sufficient to reconcile the universal participation rate that standard portfolio theory predicts with what we observed in our data. When we look at a sample of wealthy sophisticated households who should not find entry costs as an impediment to own stocks, there is still an important percentage of them who are not participating in the stock market at all. We believe that this calls for a more structural approach in order to explain the stockholding puzzle. We also showed how the decision of holding stock is positively correlated with the decision of holding safe financial assets and the decision of holding pension plans and negatively correlated with the decision of holding real estate and debt.

Acknowledgments I would like to thank the Editor, two anonymous referees, Larry Kotlikoff, Olympia Bover, Jordi Jaumandreu, Ignacio Hernando and Francisco Pino for helpful comments. All remaining errors are my own. I thank the Fundacion Ramon Areces for financial support.

Open Access This article is distributed under the terms of the Creative Commons Attribution License which permits any use, distribution, and reproduction in any medium, provided the original author(s) and the source are credited.

\section{Appendix A: Simple OLS without selection variables}

See Table 7.

\section{Appendix B: Industry of employment in Survey of Consumer Finances}

Question X7402 on the SCF questionnaire reads as follows: 'what kind of business or industry do you work in?' This same question is also asked to the spouse/partner of the household head (question X7412). The answer to the question is coded following the Census 2006 4-digit industry code. However, due to privacy concerns, the FRB has collapsed all the industry codes into only six different ones for the publicly available data set. Individuals who work for the financial industry are coded together with those who work for Software Publishing, Data Processing, Employment and Business Support Services, Security Services and Report and Maintenance. Because of this, we cannot determine exactly if a household member works in the financial industry or not. For the purpose of constructing our sophisticated household variable we have decided to consider all the households working in the aforementioned industries. In order to get an idea of the distortion introduced in our sample because of this code merging, we look at the 2007 US Economic Census. There were a total of 17,610,220 employees combining all the sectors mentioned above, of those, $50 \%$ were employed in the financial industry. Almost $11 \%$ worked for Repair and Maintenance and Security Services. Since our sample of sophisticated households only includes those with a college degree we can assume there will not be many of those in our sample. Employment support services represents $30 \%$ of the total employment, so our sample could be contaminated by those. However, we are looking at households whose wealth is above the median of the whole population, and, fortunately for us, there is an important divergence on the salaries of both groups. The average annual salary for financial industry 
Table 7 Share of funds invested on risky assets

\begin{tabular}{|c|c|c|c|c|}
\hline & \multicolumn{2}{|l|}{ Spain } & \multicolumn{2}{|l|}{ US } \\
\hline & Direct & Indirect & Direct & Indirect \\
\hline \multirow[t]{2}{*}{ Married } & -0.012 & -0.012 & $-0.017^{*}$ & $-0.034 * * *$ \\
\hline & $(0.021)$ & $(0.019)$ & $(0.010)$ & $(0.007)$ \\
\hline \multirow[t]{2}{*}{ Family size } & -0.008 & -0.013 & $0.008 * *$ & $0.008 * * *$ \\
\hline & (0.009) & $(0.008)$ & $(0.003)$ & $(0.003)$ \\
\hline \multirow[t]{2}{*}{ College } & $0.040 * * *$ & $0.042 * * *$ & $-0.028 * * *$ & $0.048 * * *$ \\
\hline & $(0.017)$ & $(0.015)$ & $(0.008)$ & $(0.006)$ \\
\hline \multirow[t]{2}{*}{ Age $31-40$} & -0.015 & 0.010 & $-0.082 * * *$ & -0.001 \\
\hline & $(0.074)$ & $(0.069)$ & $(0.019)$ & $(0.015)$ \\
\hline \multirow[t]{2}{*}{ Age $41-50$} & -0.034 & 0.040 & $-0.080 * * *$ & 0.019 \\
\hline & $(0.071)$ & $(0.068)$ & $(0.019)$ & $(0.014)$ \\
\hline \multirow[t]{2}{*}{ Age $51-60$} & -0.007 & 0.047 & -0.015 & $0.073 * * *$ \\
\hline & $(0.071)$ & $(0.068)$ & $(0.017)$ & $(0.014)$ \\
\hline \multirow[t]{2}{*}{ Age $61-70$} & 0.027 & 0.091 & 0.001 & $0.129 * * *$ \\
\hline & $(0.069)$ & $(0.067)$ & $(0.018)$ & $(0.014)$ \\
\hline \multirow[t]{2}{*}{ Age $>70$} & 0.102 & $0.180 * * *$ & $0.114 * * *$ & $0.211 * * *$ \\
\hline & $(0.071)$ & $(0.068)$ & $(0.018)$ & $(0.015)$ \\
\hline \multirow[t]{2}{*}{ Income } & $2.7 e-08$ & $8.9 \mathrm{e}-08 * * *$ & $7.13 \mathrm{e}-10^{*}$ & $2.31 \mathrm{e}-09^{* * * *}$ \\
\hline & $(3.0 \mathrm{e}-08)$ & $(3.0 \mathrm{e}-08)$ & $(4.23 e-10)$ & $4.22 \mathrm{e}-10$ \\
\hline \multirow[t]{2}{*}{ Net wealth } & $5.4 \mathrm{e}-09 * * *$ & $5.4 \mathrm{e}-09 * * *$ & $4.26 \mathrm{e}-10^{* * * *}$ & $3.61 \mathrm{e}-10^{* * * *}$ \\
\hline & $(1.3 \mathrm{e}-09)$ & $(1.3 \mathrm{e}-09)$ & $(4.52 \mathrm{e}-11)$ & $(4.26 \mathrm{e}-11)$ \\
\hline \multirow[t]{2}{*}{ Seeking some risk } & $0.038^{* *}$ & $0.060 * * *$ & 0.016 & $0.065 * * *$ \\
\hline & $(0.018)$ & $(0.018)$ & $(0.012)$ & $(0.009)$ \\
\hline \multirow[t]{2}{*}{ Seeking fair risk } & $0.136^{* * * *}$ & $0.149 * * *$ & $0.034 * * *$ & $0.119 * * *$ \\
\hline & $(0.033)$ & $(0.033)$ & $(0.012)$ & $(0.009)$ \\
\hline \multirow[t]{2}{*}{ Seeking a lot of risk } & $0.144 * * *$ & $0.244 * * *$ & $0.063 * * *$ & $0.135 * * *$ \\
\hline & $(0.055)$ & $(0.052)$ & $(0.016)$ & $(0.013)$ \\
\hline \multirow[t]{2}{*}{ Constant } & $0.329 * * *$ & $0.379 * * *$ & $0.282 * * *$ & $0.249 * * *$ \\
\hline & $(0.068)$ & $(0.064)$ & $(0.019)$ & $(0.015)$ \\
\hline Observations & 1,513 & 1,829 & 1,388 & 2,374 \\
\hline
\end{tabular}

Standard errors in parentheses

$* * * p<0.01, * * p<0.05, * p<0.1$

employees was \$76,037, while for Employment and Business Support Services it was $\$ 28,363$. All in all, we can say that probably a great majority of our final sample of sophisticated households' sample is employed in the financial services industry.

\section{Appendix C: Probit models}

See Table 8 . 
Table 8 Participation on risky assets

\begin{tabular}{|c|c|c|c|c|}
\hline & \multicolumn{2}{|l|}{ Spain } & \multicolumn{2}{|l|}{ US } \\
\hline & Direct & Indirect & Direct & Indirect \\
\hline \multirow[t]{2}{*}{ Married } & $0.234 * * *$ & $0.187 * * *$ & $0.382 * * *$ & $0.386 * * *$ \\
\hline & $(0.052)$ & $(0.049)$ & $(0.010)$ & $(0.025)$ \\
\hline \multirow[t]{2}{*}{ Family size } & 0.005 & -0.018 & $-0.030^{* * * *}$ & $-0.073^{* * * *}$ \\
\hline & $(0.021)$ & $(0.008)$ & $(0.09)$ & $(0.009)$ \\
\hline \multirow[t]{2}{*}{ College } & $0.535^{* * *} *$ & $0.501 * * *$ & $0.684 * * *$ & $0.754 * * *$ \\
\hline & $(0.047)$ & $(0.047)$ & $(0.021)$ & $(0.021)$ \\
\hline \multirow[t]{2}{*}{ Age $31-40$} & 0.047 & 0.218 & 0.017 & $0.278 * * *$ \\
\hline & $(0.138)$ & $(0.135)$ & $(0.045)$ & $(0.041)$ \\
\hline \multirow[t]{2}{*}{ Age 41-50 } & 0.173 & $0.342 * * *$ & $0.278 * * *$ & $0.605 * * *$ \\
\hline & $(0.133)$ & $(0.130)$ & $(0.042)$ & $(0.038)$ \\
\hline \multirow[t]{2}{*}{ Age 51-60 } & $0.468 * * *$ & $0.504 * * *$ & $0.410 * * *$ & $0.769 * * *$ \\
\hline & $(0.132)$ & $(0.131)$ & $(0.041)$ & $(0.039)$ \\
\hline \multirow[t]{2}{*}{ Age $61-70$} & $0.578 * * *$ & $0.708 * * *$ & $0.600 * * *$ & $0.958 * * *$ \\
\hline & $(0.132)$ & $(0.131)$ & $(0.044)$ & $(0.042)$ \\
\hline \multirow[t]{2}{*}{ Age $>70$} & $0.704 * * *$ & $0.817 * * * *$ & $0.887 * * *$ & $1.098 * * *$ \\
\hline & $(0.131)$ & $(0.131)$ & $(0.045)$ & $(0.044)$ \\
\hline \multirow[t]{2}{*}{ Income } & $3.1 \mathrm{e}-06^{* * * *}$ & $5.6 \mathrm{e}-06^{* * *}$ & $1.90 \mathrm{e}-08 * * *$ & $2.03 \mathrm{e}-07 * * *$ \\
\hline & $(4.0 \mathrm{e}-07)$ & $(5.4 \mathrm{e}-07)$ & $(2.93 \mathrm{e}-09)$ & $1.74 \mathrm{e}-08$ \\
\hline \multirow[t]{2}{*}{ Net wealth } & $2.3 \mathrm{e}-07 * * *$ & $2.7 \mathrm{e}-07 * * *$ & $1.36 \mathrm{e}-09 * * *$ & $8.16 \mathrm{e}-09 * * *$ \\
\hline & $(2.5 \mathrm{e}-08)$ & $(2.4 \mathrm{e}-08)$ & $(2.54 \mathrm{e}-10)$ & $(1.07 \mathrm{e}-09)$ \\
\hline \multirow[t]{2}{*}{ Seeking some risk } & $0.926 * * *$ & $0.922 * * *$ & $0.683 * * *$ & $0.890 * * *$ \\
\hline & $(0.050)$ & $(0.051)$ & $(0.028)$ & $(0.025)$ \\
\hline \multirow[t]{2}{*}{ Seeking fair risk } & $0.824 * * *$ & $0.793 * * *$ & $0.906 * * *$ & $0.116 * * *$ \\
\hline & $(0.114)$ & $(0.121)$ & $(0.031)$ & $(0.031)$ \\
\hline \multirow[t]{2}{*}{ Seeking a lot of risk } & $0.790 * * *$ & $0.650 * * *$ & $0.978 * * *$ & $0.925 * * *$ \\
\hline & $(0.198)$ & $(0.183)$ & $(0.016)$ & $(0.047)$ \\
\hline \multirow[t]{2}{*}{ Constant } & $-2.045 * * *$ & $-1.960 * * *$ & $0.282 * * *$ & $-2.076^{* * * *}$ \\
\hline & $(0.133)$ & $(0.132)$ & $(0.019)$ & $(0.045)$ \\
\hline Observations & 5,962 & 5,962 & 4,418 & 4,418 \\
\hline
\end{tabular}

Standard errors in parentheses

$* * * p<0.01, * * p<0.05, * p<0.1$

\section{References}

Alessie R, Hochguertel S, van Soest A (2000) Household portfolios in the Netherlands. CentER for Economic Researc, Tilburg University, Tilburg (discussion paper 55)

Bertaut C (1998) Stockholding behaviour of us households: evidence from the 1983-1989 survey of consumer finances. Rev Econ Stat 80:263-275

Bertaut C, Starr-McCluer M (2000) Household portfolios in the united states. Federal Reserve Board Discussion Series (26) 
Bover O (2008) The spanish survey of household finances (eff): description and methods of the 2005 wave. Banco de Espa na, Occasional Paper (0308)

Bucks BK, Kennickell AB, Mach TL, Moore KB (2009) Changes in U.S. family finances from 2004 to 2007: evidence from the survey of consumer finances. Fed Reserv Bull 95:A1-A55

Christelis D, Georgarakos D, Haliassos M (2013) Differences in portfolios across countries: economic environment vs household characteristics. Rev Econ Stat 95(1):220-236

Davis SJ, Kluber F, Willen P (2006) Borrowing costs and the demand for equity over the life-cycle. Rev Econ Stat 88(2):348-362

Green WH (1997) Econometric analysis. Macmillan, New York

Guiso L, Jappelli T (2000) Household portfolios in italy. Center for Economic Policy Research (2549)

Guiso L, Haliasos M, Japelli T (2002) Household portfolios. MIT press, Cambridge

Guiso L, Haliassos M, Jappelli T (2003) Household stockholding in Europe: where do we stand and where do we go? Econ Pol 18(36):123-170

Haliassos M, Bertaut C (1995) Why do so few hold stocks? Econ J 105:1110-1129

Jappelli T (2010) Economic literacy: an international comparison. Econ J 120:429-451

King M, Leape J (1998) Wealth and portfolio composition: theory and evidence. J Public Econ 69:155-193

Kocherlakota N (1996) The equity premium: it's still a puzzle. J Econ Lit 34:42-71

Markowitz H (1952) Portfolio selection. J Financ 7:77-91

Tobin J (1958) Liquidity preference as behaviour towards risk. Rev Econ Stat 25:68-85

Vissing-Jorgensen A (2000) Towards an explanation of household portfolio choice heterogeneity: nonfinancial income and participation cost structures. University of Chicago Mimeo

Vissing-Jorgensen A (2003) Perspectives on behavioral finance: does irrationality disappear with wealth? Evidence from expectations and actions. In: Gertler M, Rogoff K (eds) NBER macroeconomics annual. MIT Press, Cambridge 